\title{
Alternative microscope for serial production for practical work with elementary school students
}

\author{
Microscópio alternativo para produção em série para trabalhos práticos com \\ estudantes do ensino fundamental
}

\author{
Jair Putzke', Carine Furlan Possati ", Bruno Cardoso Conrad 'I', \\ Marisa Terezinha Lopes Putzke IV
}

\begin{abstract}
The teaching of life sciences in elementary school faces a major problem: the lack of materials for laboratory practice. This lack of equipment results in many cases in the transformation of the class into theoretical information routines, discouraging the student to care for nature. The sense of admiration that should be worked with at this level of education is now neglected and the trainee is enchanted with technology and not dedicated to caring for nature. Taking the student to a set of activities that return his taste for nature, especially with the use of alternative microscopy was the objective of the present work. Using alternative materials, especially magnifying glasses from various equipment, three alternative microscopes were assembled, which were tested and worked with teachers of a school to verify their potential use in class. The assembled equipment proved to be efficient for microscopic studies, especially to arouse the student's interest in the subject, with the possibility of even having his own equipment at home and continuing to develop a sense of charm for nature. The increase achieved was 300 times. Possible activity kits were assembled, which are presented in the form of routine work with a microscopy laboratory. The evaluation of the equipment allows the possibility of working disciplines such as biology, chemistry, physics and mathematics in an interdisciplinary manner.
\end{abstract}

Palavras-chave: Students; Science; Microscope; Prototypes.

\section{RESUMO}

O ensino de ciências biológicas no ensino fundamental esbarra num grande problema: a falta de materiais para a prática de laboratório. Esta inexistência de equipamentos resulta em muitos casos na transformação da aula em rotinas de informações teóricas, desestimulando o estudante para o cuidado com a natureza. $O$ sentido de admiração, que deveria ser trabalhado com este nível do ensino passa a ser deixado de lado e o formando acaba por se encantar com a tecnologia e não se dedica ao cuidado com a natureza. Levar o estudante a um conjunto

I Doutor, Professor da Universidade Federal do Pampa, Campus São Gabriel. E-mail: jrputzkebr@yahoo.com. ORCID: https://orcid.org/0000-0002-9018-9024.

" Especialista, Universidade Federal do Pampa, Campus São Gabriel. E-mail: carfposs@hotmail.com. ORCID: https://orcid.org/0000-0003-4799-4578.

III Graduando, Curso de Ciências Biológicas, Universidade Federal do Pampa, Campus São Gabriel. E-mail: brunocardosoconrad83@gmail.com. ORCID: https://orcid.org/0000-0001-6642-3768.

IV Doutora, Departamento de Ciências da Vida, Universidade de Santa Cruz do Sul. E-mail: marisa@unisc.br. ORCID: https://orcid.org/0000-0002-2004-8410. 
de atividades que the devolvam o gosto pela natureza, em especial com o uso de microscopia alternativa foi objetivo do presente trabalho. Com o uso de materiais alternativos, em especial lentes de aumento de equipamentos diversos, foram montados três microscópios alternativos, os quais foram testados e trabalhados com professores de uma escola para verificar o seu uso potencial em classe. Os equipamentos montados se mostraram eficientes para estudos microscópicos, em especial para despertar no aluno o interesse pelo tema, com a possibilidade até dele ter seu próprio equipamento em casa e continuar amadurecendo o desenvolvimento de um sentido de encanto pela natureza. $\mathrm{O}$ aumento conseguido foi de 300 vezes. Foram montados kits de atividades possíveis, as quais são apresentadas na forma de rotina de trabalho com laboratório de microscopia. A avaliação do equipamento permite a possibilidade de trabalhar disciplinas como biologia, química, física e matemática de maneira interdisciplinar.

Keywords: Alunos; Ciência; Microscopia; Protótipos.

\section{INTRODUCTION}

Working with microscopy has always attracted the young to understand the immense natural world, but from a microscopic "point of view". Nowadays, due to the difficulty of having adequate funds to acquire, or because there are only one equipment in the school laboratory, many of them have changed theory-practice only for theory, resulting in total disinterest in the complexity of the microscopic world on the part of the young. There is also a bit of "disinterest" or lack of knowledge of the teacher, since practical classes are more laborious than theoretical and need training.

This leads to a difficulty in understanding various aspects of the biological sciences what results in a number of problems for the student's future life, including the difficulty in accepting natural complexity and in understanding unexplored topics, such as the indiscriminate use of pesticides (impact on microorganisms) and distrust of vaccines, for example.

The science discipline can be one of the most attractive if it has the practical part associated or becomes one of the worst, because it prioritizes only the theory (Krasilchik, 2008; Bomfim \& Dias, 2013).

The discipline of natural sciences in elementary school is done in a way that students develop skills that allow them to understand the world and act as individuals and as citizens, using knowledge of a scientific and technological nature (Brasil, 2002). However, 
the absence of science labs in some schools prevents the microscopy content from being fully worked with students.

According to the school census conducted by Inep $(2018)$, only $11 \%(19,380)$ of primary schools had science laboratories in their facilities. Optical microscopes are expensive, require electrical power and maintenance. An alternative microscope is intended to fill this gap because it is an object that can be transported to various locations because it is simple, lightweight, easy to repair and requires no electrical power (unless the light is bright). artificial) (Silva et al., 2019).

Much of the practice in microscopy does not end up being also due to the fear or lack of knowledge of the teacher to use the equipment, the lack of maintenance and the lack of alternatives (Pagliarini \& Rodrigues, 2012).

With the use of many lenses in various electronic equipment nowadays (CD players, DVD players, mice, etc.), the possibility of making alternative microscopy equipment arises, which eliminate most of the situations of the previous paragraph, as they enable that each student can set up his microscope and even take it home, continuing the activities started in class (Walau et al., 2008; Brito, 2015; Sepel et al., 2011).

The use of cell phones as a way of enlarging images and photography is also explored, and there are even alternative microscopes for this purpose, as presented by Hewitt (2013), which gives increases of up to $175 x$, but the use of cell phones in the classroom. It is still being a barrier. But from comments from people who set up such a microscope and exposed on the site, the increase has been around 10x, possibly illustrating fake news. Silva et al. (2017) built a microscope similar to the site in Brazil and attested an increase of $170 \mathrm{x}$. Other types of alternative microscopes have been developed and tested with students (Silva et al., 2009; Sepel et al., 2011; Freitas et al., 2014; Prates et al., 2015; Soga et al., 2017; Souza e Montes, 2017; Silva et al., 2019), each with its own peculiarities and offering increases of 71 to $350 \mathrm{x}$. But none of these microscopes resembles any of those actually used in laboratories, being clumsy and unattractive to the young. 
The cost of buying a microscope on the internet varies widely, but in general a Monocular Biological Microscope can be purchased for as little as $\$ 40$. The costs of materials used in alternative microscopes in the aforementioned works were close to $\$ 5$, which is already a big savings, above all (Freitas et al., 2014).

Practical work of microscopy can result in the development of various general skills, including: observing, describing, identifying, comparing data, experimenting, drawing tables, graphs and diagrams, systematizing through texts and reports, interpreting data, relating and adding ideas (Caldera, 2005).

Therefore, conducting microscopic studies is paramount in elementary school and its implementation contributes a lot to the student's education in science, and should create alternatives for the teacher's work, which is proposed and tested in the present work. A simple microscope is much cheaper than those already presented by other authors, but at least similar to the microscope of a scientist, which is not among the microscopes already presented in the literature.

\section{MATERIAL AND METHODS}

Looking in the literature, a microscope construction project was developed and experiments that could be used for content development, using alternative and low cost materials, especially those performed by Walau et al. (2008) and Sepel et al. (2011). The construction of the microscope and the experiments were carried out with the direct participation of teachers from rural schools and students involved in the project. Practices with plant tissues, water with protozoa, collected in the school environment were developed to test the equipment and elaborate routine activities. The project was evaluated through student involvement and the degree of interest aroused and the functional and effective effectiveness of the microscope.

Alternative slides were assembled using plastic from pet bottles and the final equipment was assembled entirely independently of those suggested by the authors, 
especially in order to develop equipment that resembled at least somewhat the microscope of scientists.

To make the final equipment were used lenses taken from computer mouses and DVD-CD players, eye pieces taken from led flashlights, and PVC (Polyvinyl Chloride) pipes and joints. Hot glue was used to adhesive the pieces, as well as screws and wire. The augmentation was detected compared to existing microscopes in the UNIPAMPA laboratory structure and the entire testing procedure was performed in their laboratory.

Three microscopes were assembled until the final one was produced, in particular to test the lenses and distance beyond the way to fix the slide. In all assembled models, the enlarged virtual image provided by the alternative microscope is designed by the combination of lenses, which are housed in a PVC adapter pipe, supported by a joint system. Prototype 01 was stabilized by the presence of two floppy disks that are vertically movable due to the presence of four height adjusting screws at their ends. The nuts below the top floppy disk threaded on the screws allow the focus to be adjusted to the frame to be viewed and the LED installed on the surface of the bottom floppy disk allows illumination. For the making of this prototype four teachers of a elementary school participated, located in the rural area of São Gabriel - RS, southern Brazil (Figure 01).

The second prototype was based on the teachers' difficulty in using the equipment 01. It used PVC pipes fixed to each other and an old shower tray base. In this equipment a bicycl flashlight allowed the light tests (Figure 02).

The third equipment combined the results of all the previous ones to finally give a scientist microscope aspect to the final version. For this purpose, a clay microscope was created, an industrial silicone mold was made after drying, and reproduced in plaster. All the necessary equipment for the microscope operation was fixed in this structure, being a set of screwable PVC joints to achieve the optimum distance from the eyepiece and objective, the "platinum" table (a folded wire) and the light source ( a reflector based on the remains of a mirror glass and a wire glued to it (Figure 03). 


\section{RESULTS AND DISCUSSIONS}

The microscope

Three types of microscopes were assembled, all based on a DVD player lens (considered ideal) mounted on a PVC threaded connection to focus:

- Microscope 01: a structure made with two floppy disks connected by 4 screws in nothing similar to usual microscopes (Figure 01);

- Microscope 02: A structure closer to that of a usual microscope, with PVC tubes and improvised base (in this case of an old shower - Figure 02).

- Microscope 03: the definitive one, with plaster body structure, made in an anterior mold of silicone coated clay (Figures 03 and 04).

Microscopes 01 and 02 were tested with teachers from different areas of the chosen school. The greatest difficulty presented by them was the difficulty to observe through the eyepiece and the fragility of the equipment 01 . From the microscope 02 , the difficulty in operating with artificial light provided by a flashlight was highlighted. Thus, a way to remedy these problems was sought in prototype 03, which became more robust and assumed the shape of a traditional, worldwide accepted microscope, since the base of the structure was made of plaster. The light used was that of a mirror to reflect the ambient light, much weaker and pleasing to the eye.

The definitive microscope cost R \$2.00 (50 cents), including plaster, PVC pipe and hot glue, as lenses were obtained from unused equipment. This is the lowest value ever announced by articles for alternative equipment, and $\$ 5$ was the lowest cost found (Freitas et al., 2014)

The microscopes were compared to a conventional one and the maximum magnification of 350 times was obtained in the definitive microscope, which was achieved by the addition of led flashlight lens as eyepiece. This one was also more similar to a real one, hence it should arouse more interest of the student for the equipment. As stated by the teachers who tested the equipment, the practice with microscopy can be applied by them in their classes, as they can plan for it. The training offered by the present work aimed 
at this aspect, since in some works it was found that there are difficulties as well because the teacher does not have training for such, as with those from Minas Gerais evaluated by some authors (Teixeira and Oliveira, 2005).

The use of this material allows the contextualization of the microscopic content worked in the classroom, since students can visualize cells of living beings and discuss about the subject in a magnification equivalent to that of a commercial microscope. Souza and Montes (2017) state that a conventional classroom can become a laboratory, as many schools do not have this environment, especially with the possibility that each student assembles their equipment, since it is very cheap and practical, and thus Each will be responsible for their material.

Figure 1 - Three of the Microscope 01 assembled for testing with teachers

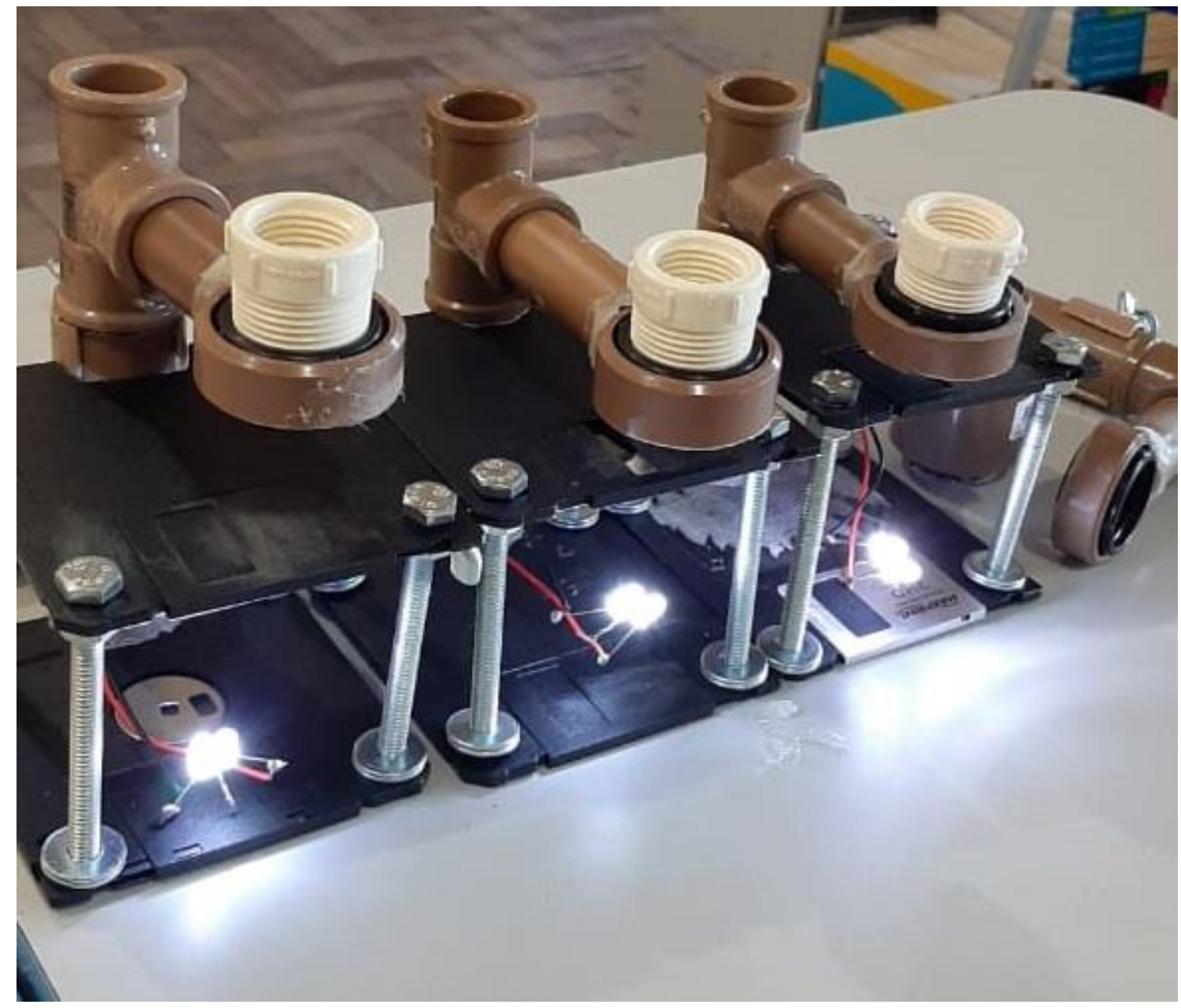

Font: Authors. 
Figure 2 - Microscope 02 fitted for length lenses experiments

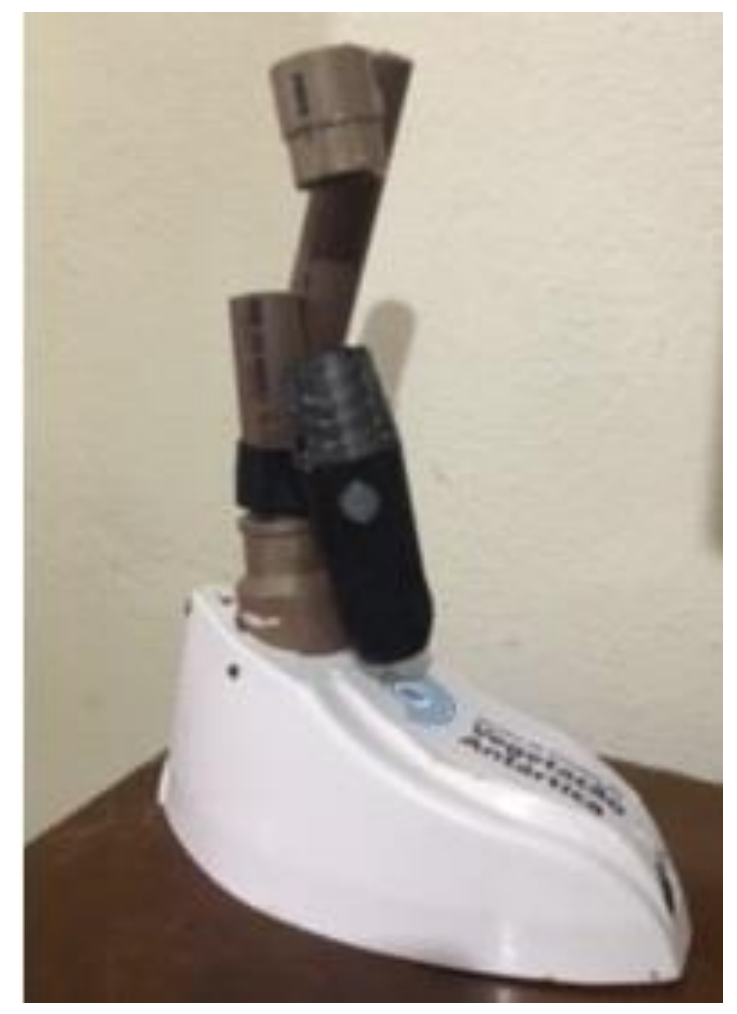

Font: Authors.

Figure 3 - Microscope 03 body preparation in clay (left), ready-made silicone mold (middle) and plaster cast being removed from the shape (right)

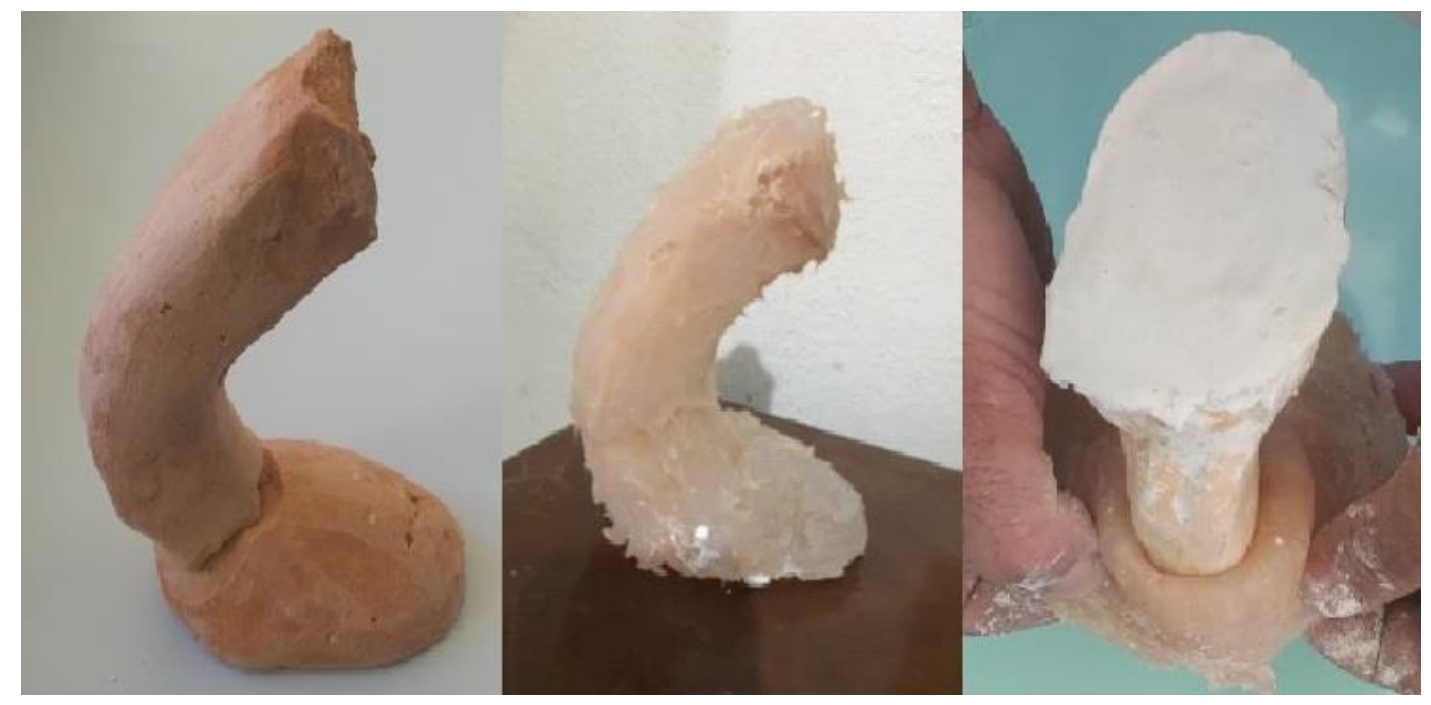

Font: Authors. 
Figure 4 -Microscope 03 in the final version for testing

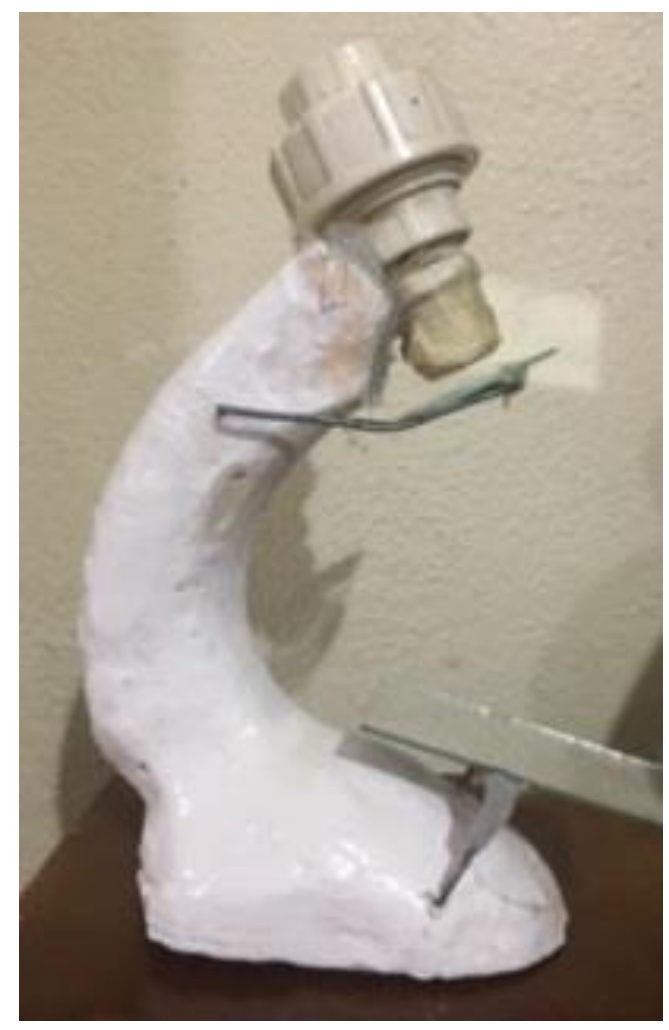

Font: Authors.

Figure 5 - Result of photos taken from cells in the microscope 03

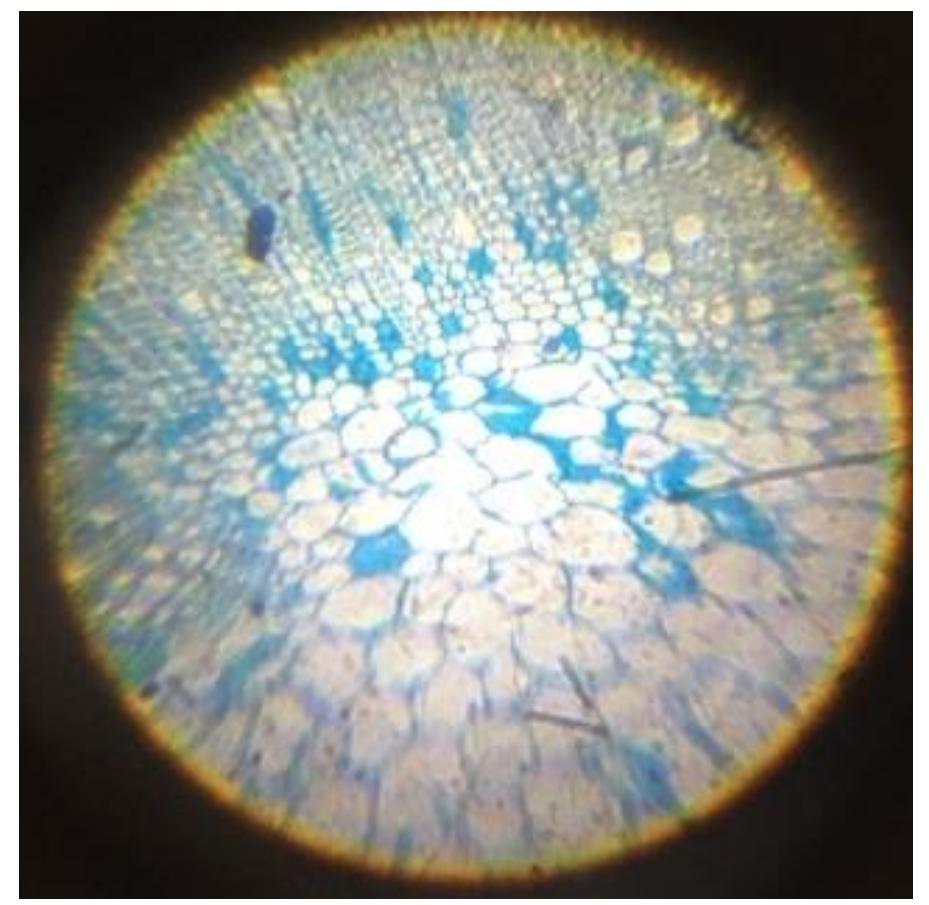

Font: Authors. 


\subsection{Developed and tested microscopic observation routines}

Here are some suggestions for practices using Microscope 03 (definitive):

\subsubsection{Physics}

1- making the parts and assembling the microscope with discussion on optics and types of lenses involved.

2- Heat and its effects on plastics (when using the hot glue gun).

\subsubsection{Chemistry}

1- Chemical reactions involving what happens to the plaster during the hardening process after the addition of water.

2- Osmosis through microscopic observation of the occurrence of plasmolysis by the addition of salt in water for mounting the slide.

3- Reaction of cells to dyes.

\subsubsection{Geology}

1- Hardness of materials, confronting plaster, metals and glass during the making of the basic structure.

\subsubsection{Biology}

1- Observation of cork cells (like Hooke in the original microscope).

2- Observation of cells in onion slide.

3- Observation of leaf cells of Elodea and moss leaves.

4- Observation of chloroplasts and their movements.

5- Observation of fern spores and sporangia.

6- Observation of fungal hyphae (bread mold).

7- Observation of microscopic beings in still water. 
8- Pasmolysis.

\subsubsection{Mathematics}

1- Algae cell count in wastewater and some natural lake; graphing with counts at different times.

2- Counting of organisms in still water and graphing with the photosynthesispredator relationship.

3- Geometric shapes of cells of different mosses.

4- Numbers of species of diverse natural environments.

\section{REFERENCES}

BOMFIM, G. S. \& DIAS, V. B. (2013). Aulas de Ciências Naturais em escolas de Ensino Fundamental I: relações existentes entre a estrutura física dos laboratórios e a realização de atividades experimentais. Atas do IX Encontro Nacional de Pesquisa em Educação em Ciências - IX ENPEC. Águas de Lindóia, SP - 10 a 14 de novembro de 2013.

BRASIL. (2002). Ministério da educação e cultura. secretaria de educação básica. Parâmetros curriculares nacionais de Biologia. Ensino Médio. Brasília: MEC/SEB. 2002.

BRITO, M. A. (2017). Criação de microscópio utilizando materiais alternativos como metodologia para trabalhar o ensino de doenças veiculadas pela água nas séries finais do ensino fundamental. $35 \mathrm{p}$.

CRUZ, J. B. (2009). Laboratórios: Curso técnico de formação para os funcionários da educação. Brasília: Universidade de Brasília.

FREITAS, J. R. DA S.; SILVA, C. E. P.; MORAIS, T. L. (2014). A Aplicabilidade do Microscópio Caseiro em Escola com Ausência de Laboratório de Ciências: Uma Proposta para o Ensino de Citologia Microscopes in Schools With No Science Laboratory: a Proposal for the Teaching of Cytology in Basic. O Trabalho no Século XXI. Anais.

HEWTT, J. (2013). A cheap, powerful digital microscope using your smartphone and an old laser pointer. Disponível em: https://www.extremetech.com/extreme/169673-a-cheap-powerfuldigital-microscope-using-your-smartphone-and-an-old-laser-pointer.

KRASILCHIK, M. (2008). Prática no ensino de Biologia. São Paulo. Editora da Universidade de São Paulo. 
PAGLIARINI, S. S. \& RODRIGUES, S. C. (2012). Análise da proposta pedagógica para ensino médio politécnico e educação profissional integrada 2011-2014 frente à realidade dos laboratórios de ciências/biologia em escolas da cidade de Santa Maria-RS. In: Encontro Nacional de Ensino de Biologia, IV, 2012, Goiás. Anais disponível em: http://eventos.ufg.br/IV ENEBIO-II EREBIO.

PRATES, G. C.; DIAS, M. B.; CANDIDO, E. L. (2015). Microscópio alternativo de baixo custo. Febrace, vol. 13, p. 1.

SEPEL, L. M. N.; ROCHA, J. B. T. \& LORETO, E. L. S. (2011). Construindo um microscópio II. bem mais simples e mais barato. Revista Genética na Escola vol. 62, p. $1-5$.

SILVA, D. R. M. E.; VIEIRA, N. P.; OLIVEIRA, A. M. (2009). O Ensino de Biologia com Aulas Práticas de Microscopia: uma Experiência na Rede Estadual de Sanclerlândia - GO. III EDIPE - Encontro Estadual de Didática e Prática de Ensino, p. 1-4, Goiânia. [Anais Online].

SILVA, C. E. P.; MORAIS, T. L.; FREITAS, J. R. S. (2017). Microscópio caseiro: uma alternativa para a melhoria do ensino de citologia nas escolas com ausência de laboratório de ciências. Anais do IV Congresso Nacional de Educação, 6 pp.

SILVA, A. de O. et al. (2019). Explorando o mundo microscópico através de leitores de DVD usados: uma experiência com alunos do Ensino Médio de escolas do interior do estado do Rio de Janeiro. Revista Científica Multidisciplinar Núcleo do Conhecimento. Ano 04, ed. 10, vol. 02, pp. 103-137.

SOGA, D. et al. (2017). Um microscópio caseiro simplificado. Revista Brasileira de Ensino de Física, v. 39, n. 4, p. 1-7.

SOUZA, F. A.; MONTES, G. A. (2017). A experimentação a serviço do ensino da biologia para alunos do Ensino Médio: microscópio caseiro. IV Congresso de Ensino, Pesquisa e Extensão da UEG.

SOUZA, F. A.; MONTES, G. A. (2019). A experimentação a serviço do ensino da biologia para alunos do Ensino Médio: microscópio caseiro. IV Congresso de Ensino, Pesquisa e Extensão da UEG.

SILVA, J. J.; BALTAR, S. L. S. M.; BEZERRA, M. L. M. B. (2019). Experimentação em ciências com o uso de um microscópio artesanal e corante alternativo. Experiências em Ensino de Ciências, $v$. 14 , n. 1, p. 344-352.

TEIXEIRA, L. C. R. S.; OLIVEIRA, A. M. (2005). A relação teoria-prática na formação do educador e seu significado para a prática pedagógica do professor de biologia. Rev. Ensaio, 7 (3): 220 242. 
WALAU, G. L. et al. (2008). Construindo um microscópio de baixo custo que permite observações semelhantes aos primeiros microscópios. Genética na Escola, 3 (2): 8 - 10. 